\title{
Evaluasi Dampak Kebijakan Bantuan Peralatan Pengolahan Pada Produksi Kerupuk Ikan Di Kecamatan Jongkong Kabupaten Kapuas Hulu
}

\author{
Hermiwati $^{1}$ \\ 1. Dinas Perikanan Kabupaten Kapuas Hulu
}

Korespondensi Penulis : hermiwatiistawa1974@gmail.com

\begin{abstract}
This research aims to describe and analyze the policy impact of providing assistance for processing fish cracker production equipment to the processing community group in Jongkong Sub-District, Kapuas Hulu Regency. From research results conducted on the fishery product processing group in Jongkong Sub-District, It is indicated that the provision for fishery processing equipment assistance has positive impacts on increasing product volume and processor income (group). In terms of effectiveness, there is a difference between yield volume and processing income from before and after assistance. In terms of efficiency, the assistance can save labor, speed up the processing process so as to increase income. The assistance fulfills the adequacy criteria because it can solve the quality problem of the processed products and is deemed adequate because the assistance is in the form of a complete package so that it is highly appreciated by the processor. The assistance meets the leveling criteria as it can be seen that all group members in the group receive the same assistance, while other groups are given in turn. Responsiveness can also be fulfilled because respondents said that the assistance is appropriate and in accordance with their needs and the equipment is used optimally. The accuracy criteria of this program can be seen that the assistance of equipment that will be very much in line with the improvement of product quality. This will increase the competitiveness and expansion of marketing. Therefore, it gives a positive value and can be recommended to be continued in the coming years.
\end{abstract}

Key words : Impact Evaluation, Fish Crackers, Jongkong Sub-District, that the Kapuas Hulu Regency 


\section{PENDAHULUAN}

Pemerintah Daerah Kabupaten Kapuas Hulu melalui Dinas Perikanan telah menyusun rencana strategis pengelolaan sumber daya perikanan dalam rangka peningkatan kesejahteraan masyarakat dengan salah satu indikatomya berupa peningkatan produksi, baik produksi dibidang perikanan tangkap, perikanan budidaya, maupun pengolahan hasil perikanan. Melalui indikator peningkatan produksi dapat terlihat berhasil atau tidaknya program program pemerintah yang telah diimplementasikan kepada masyarakat. Salah satu kegiatan dibidang perikanan yang dapat memberikan nilai tambah ekonomi bagi masyarakat adalah kegiatan Pengolahan Hasil Perikanan. Di Kabupaten Kabupaten Kapuas Hulu, kegiatan Pengolahan hasil perikanan cukup berkembang apabila dibandingkan 10 ( sepuluh) tahun yang lalu. Jenis pengolahan yang dilakukan yaitu pengolahan kerupuk ikan, lainnya, akan tetapi apabila dibandingkan antara produksi dibidang perikanan tangkap dan produsi dibidang perikanan budidaya dengan produksi pengolahan hasil perikanan terdapat perbedaan yang sangat jauh, padahal hasil dan produksi perikanan tangkap dan budidaya merupakan bahan baku produksi pengolahan hasil perikanan. lni menunjukkan bahwa produksi perikanan tangkap dan budidaya masih banyak yang dijual dalam bentuk row material atau bahan baku sehingga hanya sedikit memberikan nilaiekonorni bagi masyarakat pelaku utama.

Indonesia dalam mendorong produksi dan produktivitas pelaku usaha kecil. Dalam teorinya, pemberian subsidi input dapat meningkatkan pendapatan dan mengurangi kendala kekurangan modal usaha pada pelaku usaha kecil. Salah satu Kabupaten yang menerima bantuan Program Bantuan Peralatan Pengolahan Produksi Kerupuk Ikanproduksi kerupuk ikan adalah Kabupaten Kapuas Hulu melalui Dinas Perikanan Kabupaten Kapuas Hulu, dimana Kabupaten Kapuas Hulu merupakan salah satu Kabupaten di Provinsi Kalimantan Barat yang terletak di hulu sungai kapuas dan menjadi sentra pengolah dan penangkapan ikan terutama dengan skala kecil-menengah dan memiliki potensi yang cukup besar sebagai penghasil produk olahan hasil perikanan. Walaupun potensi yang ada cukup besar, namun pengolahan hasil perikanan di Kabupaten Kapuas Hulu masih banyak menghadapi permasalahanpermasalahan, terutama yang menyangkut sarana dan prasarana, modal, sumber daya manusia dan pendanaan.

Kecamatan Jongkong Kabupaten Kapuas Hulu yang menjadi Lokus dalam penelitian ini memperoleh informasi tentang jenis bantuan peralatan pengolahan dari Dinas Perikanan dan Program Bantuan Peralatan Pengolahan pada Produksi Kerupuk Ikan kepada Kelompok Permata dan Mandiri Kecamatan Jongkong yang tergabung dalam Kelompok Usaha Mandiri ( KUB ) pengolah Kecamatan Jongkong 
Program Bantuan Peralatan Pengolahan Produksi Kerupuk Ikan bagi kelompok pengolah merupakan salah satu bentuk kebijakan distributif yang telah ditetapkan oleh Pemerintah Kabupaten Kapuas Hulu dan telah dapat di implementasikan dengan anggaran yang tidak kecil. Tentunya kebijakan publik dengan tipe kebijakan distributive tersebut diharapkan dapat mencapai tujuan yang diinginkan yakni dapat meningkatkan produktivitas pengolah (pendapatan pengolah) sehingga dapat mendorong tercapainya kesejahteraan hidup keluarganya.

Namun demikian hingga saat ini belum pernah dilakukan evaluasi secara mendalam apakah Program Bantuan Peralatan Pengolahan Produksi Kerupuk Ikantersebut benar-benar dapat meningkatkan produktivitas kelompok pengolah sehingga mendorong tercapainya kesejahteraan keluarga pengolah tersebut. Jika Program Bantuan Peralatan Pengolahan Produksi Kerupuk Ikan tersebut memang benar-benar memiliki dampak positif sebagaimana diharapkan tentunya program tersebut dapat lebih diperluas dan dikembangkan.

Oleh karena itu evaluasi Program Bantuan Peralatan Pengolahan Produksi Kerupuk Ikan sangat urgen untuk dilakukan.

Berdasarkan pada kondisi tersebut maka penulis ingin melakukan kajian dalam bentuk penelitian dengan topik Evaluasi Program Bantuan Peralatan Pengolahan Produksi Kerupuk di Kecamatan Jongkong.

Evaluasi Dampak Kebijakan Bantuan
Peralatan Pengolahan Pada Produksi Kerupuk Ikan Di Kecamatan Jongkong Kabupaten Kapuas Hulu " ini diarahkan untuk menilai tingkat keberhasilan yang dapat dicapainya yakni dalam meningkatkan produktivitas atau pendapatan pengola

Setiap kebijakan publik yang ditetapkan oleh pemerintah selalu didasarkan pada adanya tujuan yang ingin dicapai melalui implementasi kebijakan publik tersebut. Dengan kata lain dapat dijelaskan bahwa kebijakan publik merupakan instrument yang digunakan oleh pemerintah untuk mencapai tujuan yang diharapkan. Hal ini sebagaimana diungkapkan oleh Hogwood dan Gunn (Wahab,1990:20) bahwa kebijakan adalah teori atau model. Artinya bahwa semua kebijakan publik mengandung asumsi-asumsi mengenai apa yang dapat dilakukan oleh pemerintah dan apa akibat atau hasil yang akan diperoleh dari implementasi kebijakan publik tersebut. Asumsi-asumsi tersebut menunjukkan adanya hubungan sebab akibat antara kebijakan publik dengan hasil yang diperoleh. Dengan kerangka konsep yang sederhana dapat ditegaskan dalam pernyataan jika $\mathrm{X}$ dilakukan maka Y akan terjadi.

Dalam konteks penelitian ini dapat dinyatakan bahwa ada hubungan sebab akibat antara Program Bantuan Peralatan Produksi Pengolahan Kerupuk Ikan dengan peningkatan pendapatan pengolah. Dengan kata lain bahwa jika Program Bantuan Peralatan Produksi Pengolahan Kerupuk Ikan 
diimplementasikan maka dapat meningkatkan pendapatan pengolah (Y). Adapun kerangka pemikiran dan teori yang telah dipaparkan secara sederhana pada bagian sebelumnya maka dapat dirumuskan hipotesis penelitian sebagai berikut: Seberapa Jauh Dampak Kebijakan Bantuan Peralatan Pengolahan pada Produksi Kerupuk Ikan di Kecamatan Jongkong Kabupaten Kapuas Hulu terhadap penghasilan masyarakat pengolah?.

\section{METODE PENELITIAN}

Penelitian ini dimaksudkan untuk mengevaluasi Program Bantuan Peralatan Pengolahan ProduksiKerupuk Ikan Pada Kelompok Pengolahan di Kecamatan Jongkong Kabupaten Kapuas Hulu. Jenis Penelitian yang digunakan dalam penelelitian ini adalah jenis penelitian evaluasi. Sedangkan paradigma penelitian dalam penelitian ini adalah penelitian kualitatif adalah satu model penelitian humanistik, yang menempatkan manusia sebagai subyek utama dalam peristiwa sosial/budaya.

Adapun macam penelitian yang digunakan dalam penelitian ini adalah penelitian evaluasi program, dimana evalusi program merupakan metode ilmiah yang digunakan untuk mengetahui efektifitas dan efisiensi sebuah program, kebijakan, proyek dan aktivitas tertentu baik yang telah lalu, yang sedang terjadi, dan usulan program yang akan datang sehingga penelitiannya dilakukan berdasarkan standar rencana dan tujuan dari program yang hasilnya dapat digunakan sebagai bahan pertimbangan untuk meningkatkan kualitas perumusan, implementasi dan hasil dari suatu proyek, kebijakan dan program.

Sedangkan apabila dilihat dari model penelitian, maka dalam penelitian ini, penulis menggunakan model evaluasi dampak (Outcome) terutama untuk meneliti sejauhmana dampakProgram Bantuan Peralatan Pengolahan Produksi Kerupuk Ikan terhadap Kelompok Pengolahan,.Evaluasi outcome tergolong sebagai salah satu teknik yang digunakan dalam melakukan evaluasi. Dari perspektif konseptual, evaluasi outcome adalah evaluasi sumatif, karena dilakukan setelah suatu program selesai dilaksanakan (ex-post). Karena sifatnya hanya dapat dilakukan ketika program telah selesai dilaksanakan, maka dari perspektif manajemen, hasil dari evaluasi outcomedapat digunakan sebagai bahan penyempurnaan program mendatang, namun sebatas pada tingkat program yang dievaluasi.

Lokasi penelitian ini adalah Di Desa Jongkong Kiri Kecamatan Jongkong Kabupaten Kapuas Hulu dan secara spesifik adalah permukiman nelayan sekaligus Pengolah Produksi Kerupuk Ikandengan alasan bahwa Desa Jongkong Kiri Kabupaten Kapuas Hulu merupakan salah satu Desa tempat bermukimnya kelompok pengolah yang telah memperoleh Program Bantuan Peralatan Pengolahan Pada Produksi Kerupuk Ikan dari Pemerintah Provinsi Kalimantan Barat melalui Dinas Perikanan Kabupaten Kapuas Hulu.

Objek penelitian ini adalah Program Bantuan Peralatan Pengolahan Produksi Kerupuk IkanPada Kelompok 
Pengolahan di Kecamatan Jongkong. Peneliti menetapkan informan penelitian sebagai berikut :

a. Kepala Dinas Perikanan Kabupaten Kapuas Hulu

b. Kepala Bidang Kelembagaan dan dan Pengolahan TPI Dinas Perikanan Kabupaten Kapuas Hulu

c. Anggota Kelompok Pengolahan Ikan ada di Kecamatan Jongkong

Dalam penelitian ini teknik pengumpulan data yang digunakan adalah :
a. Teknik observasi,
b. Wawancara.
c. Dokumentasi.

Untuk memperoleh data yang kredibel peneliti melakukan triangulasi sumber dengan cara pengecekan (checkrecheck) data melalui beberapa sumber data. Data dianggap kredibel jika data yang diperoleh dari sumber yang satu dengan sumber yang lain ada kesesuaian atau kecocokan. Tidak ada kontradiktif antara data yang diperoleh dari sumber yang satu dengan data yang diperoleh dari sumber yang lain. Selain melakukan triangulasi data berdasarkan sumber data peneliti juga melakukan triangulasi teknik yakni dengan cara melakukan pengecekan data dari hasil pengumpulan data melalui teknik pengumpulan data yang satu dengan teknik pengumupulan data yang lain. Data yang diperoleh melalui wawancara di-crosscheck dengan data dari hasil observasi atau dokumen yang ada dan sebaliknya.

\section{HASIL DAN PEMBAHASAN}

Untuk menganalisis hasil evaluasi dampak program pada penelitian ini peneliti mengacu pada kriteria yang telah ditetapkan oleh Dunn (1994:610) yang mencakup : efektivitas, efisiensi, kecukupan, perataan, responsivitas dan kelayakan. Keenam kriteria tersebut berdasarkan data yang diperoleh di lapangan dapatdi paparkan secara rinci sebagai berikut.

\section{Kriteria Efektivitas}

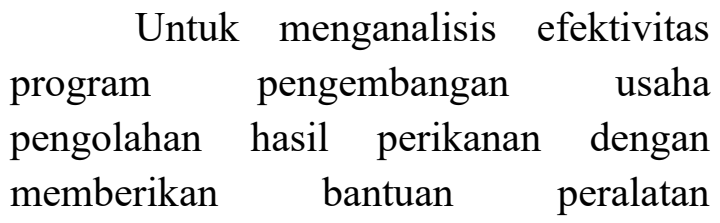
pengolahan berupa dandang pengukus, wajan/kuali, hand sealer, mesin penggilin, frezeer, baskom stainles, timbangan dalam penelitian ini desin penelitian yang digunakan adalah model desin penelitian Pretest-Postest Comparison Group. Model ini dianggap tepat karena dengan model ini peneliti dapat mengeliminir sporius dan confounding variable (variable palsu dan variable pengganggu). Dalam mengoperasionalkan model ini diperlukan adanya data dari dua kelompok pengolah yang memiliki karakteristik yang mirip sama (samasama kelompok pengolah tradisional atau kecil dengan sarana dan prasarana yang sama atau mirip pada wilayah lokasi pengolah yang sama) namun satu kelompok memperoleh program bantuan pengembangan usaha pengolahan hasil perikanan sementara kelompok yang lain tidak memperoleh program bantuan 
pengembangan pengolahan hasil perikanan.

Perbedaan kedua kelompok pengolah tersebut hanya pada peralatan yang di gunakan untuk mengolah kerupuk Model desin penelitian ini membandingkan kondisi sebelum dan sesudah adanya program dari kelompok treatment (sasaran program) dan kelompok pembanding. Jika kondisi sesudah ada program berbeda dengan kondisi sebelum ada program berarti perubahan kondisi tersebut sebagai akibat adanya program.

Dari data menunjukkan bahwa hasil pengolahan kerupuk ikan oleh pengolah baik sebelum memperoleh bantuan peralatan pengolahan maupun setelah memperoleh bantuan peralatan pengolah pada prinsipnya mengalami adanya perbedaan yang cukup berarti. Pembuatan kerupuk secara tradisional dilaksanakan dengan beberapa tahapan yaitu penyiapan bahan, pembuatan adonan, pengukusan / perebusan, pemotongan, pengeringan dan pengepakan .Penyiapan bahan dilakukan dengan menentukan dua bahan baku utama, yaitu ikan dan tepung.

Pemilihan ikan dilakukan dengan memilih jenis ikan yang cocok serta memiliki kualitas baik. Jenis ikan yang digunakan antara lain ikan Belidak, ikan Toman, ikan Gabus atau ikan lainnya. Sedangkan tepung yang digunakan adalah tepung tapioka dan tepung terigu.Langkah selanjutnya setelah bahan-bahan disiapkan maka dilakukan pembuatan adonan. Ikan yang telah disiapkan direbus dan selanjutnya ikan yang telah direbus tersebut dipisahkan dari tulangnya. Kemudian dicampur dengan tepung untuk dibuat menjadi adonan yang siap untuk dicetak menjadi bulatan atau lonjong. Proses selanjutnya adonan tersebut direbus/dikukus selama kurang lebih 2 jam, kemudian ditiriskan dan didinginkan. Pemotongan dilakukan secara cermat agar memperoleh hasil dengan lebar/tebal pemotongan yang sama. Kemudian dilakukan pengeringan dengan menjemur di bawah sinar matahari pada tempat yang telah disiapkan. Pengeringan harus dilakukan sampai kering benar, biasanya sekitar tiga hari berturut-turut. Sebab jika tidak sampai kering benar akan berjamur .Proses terakhir adalah pengepakan yang dilakukan dengan peralatan sederhana dan kemudian siap dipasarkan.

Berdasarkan data dapat dijelaskan bahwa Program Bantuan Peralatan Pengolahan Pada Produksi Kerupuk Ikan dalam bentuk pemberian bantuan Alat pengolahan berupa Dandang Pengukus, Wajan / Kuali, Tutup Kuali Mesin Penggiling Ikan kepada pengolah tradisional yang ada di Kecamatan Jongkong khususnya dan Kabuapetn Kapuas Hulu umumnya dapat meningkatkan pendapatan pengolah sebesar Rp.1.930.000,- setiap bulannya. Ini berarti ada peningkatan pendapatan pengolah di Kecamatan Jongkong sebesar ( 1.930.000. : 3.050.000. ) x 100\%= $\mathbf{6 3 , 2 7} \%$. Oleh karenanya hipotesis yang telah dirumuskan dalam penelitian ini yakni Program Bantuan Peralatan Pengolahan Pada Produksi Kerupuk 
Ikan Di Kecamatan Jongkong Kabupaten Kapuas Hulu Sangat Berdampak Positif Terhadap Peningkatan Pendapatan Pengolah Dapat Diterima Kebenarannya.

Peningkatan pendapatan pengolah di Kecamatan Jongkong terbukti kebenaranya karena sangat berdampok positif terhadap pendapatan pengolah, seperti yang telah dijelaskan di bagian sebelumnya bahwa peningkatan pendapatan dari produksi olahan kerupuk ikan dari pengolah rata-rata perbulan hanya sebesar $12.79 \mathrm{~kg}$ dan dengan harga Rp.25.000,- per $\mathrm{kg}$ berarti = Rp.319.750. Sementara biaya operasional pengolahan kerupuk ikan rata-rata per bulan adalah sebesar Rp.400.000,-, dan biaya operasional pebuatan kerupuk ikan rata-rata per bulan hanya Rp.200.000,-. Ini berarti biaya operasional per bulan dapat dihemat sebesar Rp200.000,-.

Dengan demikian dari hasil analisis tersebut di atas dapat ditarik kesimpulan awal bahwa Program Bantuan Peralatan Pengolahan Pada Produksi Kerupuk Ikan Di Kecamatan Jongkong telah dapat memenuhi kriteria efektivitas. Dengan demikian dari hasil analisis tersebut peneliti beranggapan bahwa Program Program Bantuan Peralatan Pengolahan Pada Produksi Kerupuk Ikan Di Kecamatan Jongkong tersebut dianggap cukup efektif dalam meningkatkan pendapatan pengolah.

\section{Kriteria Efesiensi}

Efisiensi merupakan salah satu kriteria yang sangat urgen untuk menilai keberhasilan suatu kebijakan atau program. Langkah awal yang perlu dilakukan untuk menganalisis efesiensi dari suatu program adalah mengukur biaya manfaat suatu program kebijakan dengan melakukan identifikasi biaya dan manfaat dari program yang dilaksanakan. Berdasarkan teori yang ada serta deskripsi data yang diperoleh dari lapangan berkaitan dengan implementasi suatu program, maka dapat diperkirakan biaya yang dikeluarkan dan manfaat yang diperoleh dari implementasi program. Begitu juga untuk menilai tingkat efisiensi Program Bantuan Peralatan Pengolahan Di Kecamatan Jongkong adalah dengan cara melakukan analisis biaya yang dikeluarkan dan manfaat yang diperoleh dalam rangka implementasi program tersebut. Pada implementasi suatu program tidak seluruh manfaat dapat diukur dengan nilai uang terutama manfaat sosial dari program tersebut. Untuk mengukur tingkat efisiensi dari Program Bantuan Peralatan Pengolahan Pada Produksi Kerupuk Ikan Di Kecamatan Jongkong dapat dipaparkan berikut ini.

Berdasarkan perhitungan bahwa B/C Ratio lebih besar dari 1 (satu) yakni 12,79 Ini menunjukkan bahwa benefit yang diperoleh pada Program Bantuan Peralatan Pengolahan Pada Produksi Kerupuk Ikan di Kecamatan Jongkong Kabupaten Kapuas Hulu jauh lebih besar dari nilai cost + investment. Dengan kata lain bahwa Program Bantuan Peralatan Pengolahan Pada Produksi Kerupuk Ikan di Kecamatan Jongkong Kabupaten Kapuas Hulu cukup efisien dan layak untuk dikembangkan lagi. 
Berdasarkan hasil analisis cost benefit tersebut di atas dapat ditegaskan bahwa Program Bantuan Peralatan Pengolahan Pada Produksi Kerupuk Ikan di Kecamatan Jongkong Kabupaten kapuas Hulu cukup efisien untuk dapat mencapai hasil yang diharapkan yakni dapat meningkatkan pendapatan pengolah.

Dengan hasil analisis yang dipaparkan di atas dapat diperoleh suatu kesimpulan bahwa Program Bantuan Peralatan Pengolahan Pada Produksi Kerupuk Ikan di Kecamatan Jongkong Kabupaten Kapuas Hulu telah dapat memenuhi kriteria efisiensi. Oleh karenanya Program Bantuan Peralatan Pengolahan Pada Produksi Kerupuk Ikan tersebut cukup beralasan jika lebih dikembangkan lagi secara lebih meluas sehingga pendapatan pengolah kecil dapat ditingkatkan dan pada akhirnya kesejahteraan keluarga pengolah dapat tercapai sebagaimana yang diharapkan. Jika hal ini dapat dilaksanakan secara kontinyu maka Program Bantuan Peralatan Pengolahan Pada Produksi Kerupuk Ikan akan dapat memberikan kontribusi dalam penanggulangan kemisikinan yang dicanangkan oleh Pemerintah.Sebagaimana telah diungkapkan bahwa sebagian besar pengolah kecil termasuk kategori warga miskin, sehingga wilayah pesisir sungai kapuas yang sebagian dihuni oleh pengolah kecil dan nelayan menjadi basis kantong-kantong kemiskinan. Oleh karenanya sangat tepat jika Program Bantuan Peralatan Pengolahan Pada Produksi Kerupuk Ikan dapat diperluas wilayah implementasinya guna memberantas kemiskinan khususnya warga pengolah.

\section{Kriteria Kecukupan}

Salah satu kriteria yang dapat digunakan untuk menganalisis dampak dari suatu implementasi kebijakan atau program adalah kecukupan. Ada dua aspek yang perlu diperhatikan dalam kriteria kecukupan yakni pertama apakah program tersebut dianggap dapat menyelesaikan masalah yang dihadapi oleh target group dan kedua adalah apakah manfat yang diperoleh dari program tersebut dirasakan cukup memadai. Ketua KUB Mandiri dari pengolah kecil di Kecamatan Jongkong menegaskan bahwa Program Bantuan Peralatan Pengolahan Pada Produksi Kerupuk Ikan yang terealisasi dalam bentuk bantuan peralatan pembuatan kerupuk ikan ( Dandang Pengukus, Tutup Dandang Wajan / Kuali, Mesin Penggiling Ikan ) yang diberikan kepada pengolah kecil di Kecamatan Jongkong memiliki nilai yang cukup tinggi terutama bagi pengolah yang sebelumnya tidak menggunakan peralayan pengolahan yang memadai pengolah dapat mengurangi biaya operasional saat mengolah ikan menjadi kerupuk ikan. Pengurangan biaya operasional ke laut tersebut cukup besar bisa mencapai 50\%. Berdasarkan analisis pada bagian sebelumnya telah dapat dijelaskan bahwa biaya operasional yang harus dikeluarkan oleh pengolah yang belum mengunakan peralatan pengolahan bantuan sebesar Rp.400.000,- sedangkan pengolah yang 
menggunakan peraralatan bantuan per bulan hanya sebesar Rp.200.000,- Jadi jelas ada selisih yang cukup besar biaya yang dikeluarkan pengolah

Memang diakui bahwa untuk meningkatkan jumlah produksi ikan yang dapat ditangkap dipengaruhi oleh beberapa faktor antara lain adalah faktor ketrsedia bahan baku berupa daging ikan dan cuaca, Dari data yang yang telah diperoleh di lapangan dapat dipahami bahwa Program Bantuan Peralatan Pengolahan Pada Produksi Kerupuk Ikan yang diwujudkan dalam bentuk bantuan peralatan pengolahan pada dasarnya cukup membantu pengolah untuk meningkatkan pendapatan mereka dengan cara menghemat biaya operasional yang dikeluarkan dalam kegiatan mencari atau menangkap ikan dilaut sebagai mata pencahariannya. Namun disisi yang lain pada dasarnya Program Bantuan Peralatan Pengolahan Pada Produksi Kerupuk Ikan belum dapat meningkatkan jumlah produksi kerupukikan yang dapat diperoleh oleh pengolah penerima manfaat rogram.

Peralatan pengolahan yang diterima pengolah memang belum sepenuhnya dapat menyelesaikan masalah yang dihadapi mereka karena ketergantungan akan bahan baku lain seperti daging ikan yang didapt dari nelayan. Dengan demikian dapat disimpulkan bahwa Program Bantuan Peralatan Pengolahan Pada Produksi Kerupuk Ikan dengan sasaran pengolah kecil memang sudah memiliki manfaat bagi pengolah kecil tersebut, namun program tersebut belum sepenuhnya dapat mengatasi masalah yang dihadapi oleh pengolah kecil dalam usaha meningkatkan pendapatan dan kesejahteraan hidup bersama keluarganya. Dengan demikian Program Bantuan Peralatan Pengolahan Pada Produksi Kerupuk Ikan ini belum dapat memenuhi kriteria kecukupan sebagai salah satu kriteria keberhasilan suatu program atau kebijakan sebagaimana dikemukakan oleh Dunn (1994:610).

\section{Kriteria Perataan}

Kriteria perataan dalam evaluasi dampak kebijakan atau program merupakan kriteria yang cukup sensitive bagi target group. Jika kriteria ini kurang dapat terpenuhi maka tidak menutup kemungkinan akan dapat menghambat proses implementasi program tersebut. Substansi pokok dari kriteria perataan ini adalah apakah semua target group telah dapat menikmati manfaat dari program tersebut.

Berdasarkan data yang diperoleh melalui wawancara dapat dipahami bahwa belum semua pengolah kecil atau tradisional yang ada di Desa Jongkong khususnya dan Kecamatan Jongkon umumnya memperoleh manfaat dari Program Bantuan Peralatan Pengolahan pada Produksi Kerupuk Ikan yang berupa bantuan Dandang Pengukus, Tutup Dandang, Wajan / Kuali, Mesin Penggeling Ikan, Baskom Stainles dan lain - lain peralatan pengolahan. Hal ini sesuai dengan apa yang diungkpkan oleh Ketua Kelompok Mandiri bahwa di Kecamatan Jongkong belum semua pengolah kecil memperoleh bantuan 
peralatan pengolahan. Pengolah yang memperoleh bantuan berupa Dandang Pengukus, Tutup Dandang, Wajan / Kuali, Mesin Penggeling Ikan, Baskom Stainles yakni Kelompok Mandiri yang beranggotakan 13 orang pengolah dan Kelompok Permata yang beranggotakan 12 orang pengolah. Jadi pengolah yang sudah memperoleh bantuan peralatan pengolahan sebanyak 25 orang pengolah. Mereka yang tidak memperoleh bantuan berupa Dandang Pengukus, Tutup Dandang, Wajan / Kuali, Mesin Penggeling Ikan, Baskom Stainles tersebut karena mereka tidak memiliki Kelompok Usaha Bersama (KUB) sebagai salah satu syarat untuk memperoleh bantaun peralatan pengolahan. Ungkapan dari ketua Kelompok Mandiri tersebut juga diungkapkan oleh anggota Kelompok Mandiri yang lain. Ada yang mengatakan bahwa mereka yang tidak memperoleh bantuan mesin peralatan karena tidak mempunyai kelompok atau menjadi anggota kelompok. Mereka yang tidak memiliki kelompok itu adalah mereka yang memang tidak sepenuhnya pengolah.

Namun pengolah kecil yang memperoleh bantuan berupa Dandang Pengukus, Tutup Dandang, Wajan / Kuali, Mesin Penggeling Ikan, Baskom Stainles tersebut baru berjumlah 2 kelompok pengolah yang beranggotakan sebanyak 25 pengolah kecil. Ini menunjukkan bahwa baru sebagian kecil dari pengolah yang berada di Kecamatan Jongkong yang sudah memperoleh bantuan mesin ben-gas. Artinya baru sebagian kecil yang dapat menikmati Program Bantuan Peralatan Pengolahan Kerupuk Ikan.

Lebih jauh pengolah anggota kelompok Mandiri menjelaskan bahwa sebenarnya ada rasa cemburu dari pengolah yang tidak memperoleh bantuan peralatan pengolahan. Namun kecemburuan tersebut tidak menimbulkan masalah di kalangan pengolah. Menurut mereka sebatas ada kecemburuan saja karena pengolah yang tidak memperoleh bantuan peralatan pengolahan tersebut menyadari sepenuhnya bahwa mereka memang tidak memenuhi persyaratan yang telah ditetapkan dalam program.

Dari data yang telah dipaparkan di atas dapat disimpulkan bahwa kriteria perataan dalam impelementasi Program Bantuan Peralatan Pengolahan Kerupuk yang diimplementasikan sejak tahun 2016 di Kabupaten Kapuas Hulu khususnya Kecamatan Jongkong belum dapat terpenuhi secara baik karena masih ada anggota pengolah yang belum dapat menikmati program tersebut. Sebagaimana ditegaskan oleh Dunn (1994:470) bahwa kritetia perataan ini berorientasi pada pencapaian rasa kesamaan hak dan rasa keadilan. Rasa kesamaan hak dan keadilan ini memang seringkali menimbulkan ketidakpuasan di kalangan masyarakat. Artinya memang tidak mudah dapat mencapai rasa kesamaan hak dan keadilan ini dapat memuaskan anggota masyarakat. Hal ini salah satu faktor penyebabnya adalah keterbatasan dana atau biaya yang diperlukan. Untuk itu jika dari hasil 
evaluasi Program Bantuan Peralatan Pengolahan Pada Produksi Kerupuk Ikan memang menunjukkan ada manfaatnya yang memadai maka tentunya pihak pemerintah akan mengembangkan program tersebut dengan target yang lebih luas. Yang jelas agar aspek kriteria perataan (kesamaan) tersebut dapat terpenuhi dengan baik maka pemberian bantuan peralatan pengolahan perlu terus dikembangkan , karena keberhasilan suatu kebijakan tidak semata-mata memenuhi criteria efektivitas dan criteria efisinsi, tetapi tidak kalah pentingnya adalah kriteria perataan agar semua anggota masyarakat yang eligible dapat meikmati manfaat kebijakan atau program tersebut.

\section{Responsivitas}

Responsivitas merupakan salah kriteria yang dapat digunakan untuk menilai atau mengukur tingkat keberhasilan atau dampak dari suatu kebijakan atau program yang telah diimplementasikan. Responsivitas ini diarahkan untuk menilai apakah kebijakan atau program tersebut sesuai dengan kebutuhan yang diharapkan oleh target group. Jika program sesuai dengan kebutuhan yang diharapkan oleh target group maka target group akan dapat dengan senang hati menerima program dan tentunya akan memanfaatkan program dengan semangat tinggi serta menikmati program tersebut. Kebijakan atau program yang dapat memenuhi kriteria responsivitas berarti program tersebut memang sesuai dengan keinginan, kemauan atau kebutuhan target group.
Begitu pula Program Bantuan Peralatan Pengolahan Pada Produksi Kerupuk Ikan di Kecamatan Jongkong Kabupaten Kapuas Hulu ini akan memiliki nilai responsivitas yang tinggi ketika program tersebut dapat diterima dengan baik oleh pengolah dan pengolah memang memanfaatkan program tersebut dengan serius dan senang hati. Kondisi demikian akan dapat tercapai ketika Program Bantuan Peralatan Pengolahan Pada Produksi Kerupuk Ikan tersebut memang sesuai dengan kebutuhan pengolah penerima program.

Berdasarkan informasi yang diperoleh dari lapangan melalui wawancara menggambarkan adanya variasi pandangan dari pengolah terhadap program Program Bantuan Peralatan Pengolahan Pada Produksi Kerupuk Ikan di Kecamatan Jongkong Kecamatan Jongkong Kabupaten Kapuas Hulu tersebut. Bagi pengolah yang sebelumnya tidak menggunakan peralatan tradisional dalam mengolah kerupuk ikan mengungkapkan bahwa program tersebut sangat tepat dan sesuai dengan kebutuhan mereka untuk meningkatkan produktivitas dan pendapatan mereka. Mereka merasa senang sekali menerima bantuan mesin peralatan pengolahan sebagai sarana untuk mengolahan kerupuk ikan. Namun bagi pengolah yang telah menggunakan peralatan yang telah memadai sebelumnya mereka tetap merasa senang dengan program tersebut walaupun kadar atau tingkat kesenangan mereka lebih rendah. Hal ini terjadi karena peningkatan produktivitas penangkapan ikan dianggap kurang 
signifikan. Secara umum menurut pengolah yang telah menggunakan mesin perahu sebelumnya bahwa hasil produksi ikan yang dapat ditangkap tidak berbeda. Mereka tetap merasa senang merima program dalam bentuk peralatan pengolahan karena program tersebut dianggap dapat meningkatkan pendapatan melalui penghematan biaya yang dikeluarkan dalam kegiatan melaut. Sebagaimana diungkapkan oleh para pengolah bahwa ada perbedaan yang cukup besar ongkos atau biaya yang harus dikeluarkan

Program Bantuan Peralatan Pengolahan Pada Produksi Kerupuk Ikan di Kecamatan Jongkong Kecamatan Jongkong Kabupaten Kapuas Hulu yang telah diimplementasikan di Kecamatan Jongkong pada dasarnya telah dapat meningkatkan pendapatan pengolah.

Dunn (1994:437) menegaskan bahwa suatu program akan dapat memenuhi kriteria renponsive ketika program tersebut dapat memuaskan kebutuhan, preferensi atau nilai dari kelompok masyarakat yang menjadi target groupnya. Suatu kebijakan atau program dikatakan berhasil jika kebijakan atau program tersebut dapat memenuhi kebutuhan aktual dari kelompok sasaran program tersebut. Dengan demikian dapat ditegaskan bahwa Program Bantuan Peralatan Pengolahan Pada Produksi Kerupuk Ikan yang telah diimplementasikan di Kabupaten Kapuas Hulu khususnya di Kecamatan Jongkong belum sepenuhnya dapat memenuhi kriteria responsivitas. Hal tersebut tercermin dari sikap pengolah yang merasa belum memperoleh kepuasan atas Program Bantuan Peralatan Pengolahan Pada Produksi Kerupuk Ikan yang telah dapat diterimanya.

\section{Ketepatan}

Ketepatan sebagai salah kriteria yang berguna untuk menentukan apakah program benar-benar bermanfaat dan dapat menyelesaikan masalah yang dihadapi oleh target group. Jika merujuk pada apa yang dikemukakan oleh Dunn (1994:438) bahwa kriteria ketepatan atau juga disebut kelayakan tidak hanya melihat dari satu kriteria namun merupakan gabungan dari berbagai kriteria keberhasilan suatu kebijakan atau program.

Berdasarkan data dan analisis yang telah dipaparkan pada bagian sebelumnya dapat disimpulkan bahwa Program Bantuan Peralatan Pengolahan Pada Produksi Kerupuk Ikan dalam bentuk pemberian bantuanberupa Dandang Pengukus, Tutup Dandang, Wajan / Kuali, Mesin Penggeling Ikan, Baskom Stainles kepada pengolah kecil belum dapat memenuhi kriteria ketepatan sebagaimana yang dikemukakan oleh Dunn. Masih perlu adanya modifikasi dan penyesuaian di berbagai aspek agar program Bantuan Peralatan Pengolahan Pada Produksi Kerupuk Ikan dapat dikatakan memenuhi kriteria ketepatan atau kelayakan suatu kebijakan atau program sebagaimana ditegaskan oleh William N. Dunn (1994:438).

Dari analisis sebelumnya sudah dapat diketahui bahwa kriteria efektivitas 
dan kriteria efisiensi relative sudah dapat terpenuhi. Namun kriteria kecukupan, kriteria perataan, kriteria responsivitas berdasarkan data dan analisis relative belum dapat terpenuhi. Oleh karenanya dapat ditegaskan bahwa Program Bantuan Peralatan Pengolahan Pada Produksi Kerupuk Ikan belum dapat memenuhi kriteria ketepatan karena program tersebut belum sepenuhnya dapat menyelesaikan masalah yang dihadapi pengolah kecil. Program tersebut masih perlu dipertimbangkan untuk lebih disempurnakan sehingga lebih komprehensif dalam mengatasi kesulitan yang dihadapi pengolah kecil untuk meningkatkan produktivitas pengolah atau pendapatan pengolah yang bermuara pada terwujudnya kesejahteraan hidup pengolah bersama keluarganya.

\section{SIMPULAN DAN REKOMENDASI}

\subsection{Simpulan}

Berdasarkan hasil analisis yang telah dipaparkan pada bagian sebelumnya berkaitan dengan Evaluasi Dampak Kebijakan Program Bantuan Peralatan Pengolahan Pada Produksi Kerupuk Ikan di Kecamatan Jongkong Kabuapetan Kapuas Hulu dapat disajikan kesimpulan sebagai berikut:

a. Produktivitas hasil pengolahan dari kelompok pengolah yang telah menerima Program Bantuan Peralatan Pengolahan Pada Produksi Kerupuk Ikan tidak mengalami perubahan atau peningkatan yang signifikan. Program Bantuan Peralatan Pengolahan Pada Produksi Kerupuk Ikan dapat meningkatkan pendapatan pengolah Kerupuk ikan penerima program bantuan peralatan pengolahan produksi kerupuk. Peningkatan pendapatan pengolah Kerupuk ikan ini sebagai dampak dari penghematan biaya operasional yang digunakan untuk melaut. Oleh karena itu dapat ditegaskan bahwa program bantuan peralatan pengolahan pada produksi kerupuk ikan cukup efektif.

b. Program Bantuan Peralatan Pengolahan Pada Produksi Kerupuk Ikan dapat dikatakan sangat efisien untuk memperoleh manfaat atau keuntungan yang memadai bagi kehidupan pengolah Kerupuk ikan ini dapat di lihat dari peningkatan pendapatan pengolah di Kecamatan Jongkong sebesar 63,27 \%. Dengan demikian Program Bantuan Peralatan Pengolahan Pada Produksi Kerupuk Ikan layak secara ekonomis (efisien) untuk diteruskan dan dikembangkan.

c. Kriteria Kecukupan dalam implementasi program bantuan peralatan pengolahan pada produksi kerupuk ikan belum dapat terpenuhi secara baik karena tidak semua kelompok yang mendapat bantuan peralatan pengolahan kerupuk ikan.

d. Program Bantuan Peralatan Pengolahan Pada Produksi Kerupuk Ikan pada dasarnya cukup menguntungkan bagi para pelaku usaha pengolahan, namun kebutuhan pengolah tidak hanya terbatas pada bantuan peralatan pengolahan semata tetapi juga perlu dilengkapi dengan ketersedian bahan baku yang cukup 
memadai agar pengolah mampu meningkatkan produktivitas dan pendapatan sehingga dapat mencapai kehidupan yang sejahtera bersama keluarganya. Oleh karena itu dapat ditegaskan bahwa kriteria responsivitas dari Program Bantuan Peralatan Pengolahan Pada Produksi Kerupuk Ikan belum dapat tercapai sepenuhnya.

e. Kriteria Ketepatan dalam Evaluasi Program Bantuan Peralatan Pengolahan Pada Produksi Kerupuk Ikan belum dapat dicapai secara maksimal karena masih ada beberapa kekurangan dari program tersebut.

\subsection{Rekomendasi}

Berdasarkan rumusan kesimpulan dari hasil Evaluasi Dampak Kebijakan Program Bantuan Peralatan Pengolahan Pada Produksi Kerupuk Ikan di Kecamatan Jongkong dapat direkomendasikan hal-hal sebagai berikut

\section{a. Program Bantuan Peralatan} Pengolahan Pada Produksi Kerupuk Ikancukup efektif dan efisien maka program tersebut dapat diteruskan dan perlu dikembangkan serta diperluas jangkauannya.

b. Pemerintah Daerah Kabupaten Kapuas Hulu perlu meningkatkan kerjasama yang lebih intensif dengan Pemerintah Pusat khususnya Departemen atau Kementerian Kelautan dan Perikanan dalam mengembangkan Program Program Bantuan Peralatan Pengolahan Pada Produksi Kerupuk Ikan dapat menikmati manfaat secara merata dan adil. c. Bantuan yang diberikan kepada pengolah Kerupuk ikan kecil melalui Program Bantuan Peralatan Pengolahan Pada Produksi Kerupuk Ikan yang berupa mesin Baskom Stainless, Mesin Penggiling Ikan, Dandang Pengukus, Tutup DandangFrezeer, Hand Sealer dan Timbangan Digital,ini di harapkan agar program tersebut benar-benar dapat memenuhi kebutuhan kelompok pengolahl untuk meningkatkan produktivitas dan pendapatannya secara signifikan sehingga program tersebut dapat memberikan kontribusi yang cukup berarti dalam menanggulangi kemiskinan di lingkungan masyarakat.

a. Berkaitan dengan peningkatan produksi kerupuk ikan di Kecamatan Jongkong hendaknya instansi yang terkait dapat memenuhi kebutuhan peralatan yang dibutuhkan oleh kelompok pengolah seperti memberikan peralatan untuk penyimpanan bahan baku agar pada saat musim panen masyarakat dapat menyetok bahan baku.

b. Hendaknya Pemerintah atau instansi terkai dapat menstabilkan harga bahan baku tepung ditingkat pengolah, saran penulis supaya Pengolah diberikan subsidi dalam pembelian bahan baku tepung tapioka. Untuk mengatasi kekurangan bahan baku ikan.

c. Dari hasil evaluasi program yang komprehensif akan dapat dijadikan landasan ilmiah atau obyektif bagi Pemerintah untuk mentukan langkah 
berikutnya yakni : apakah program tersebut dapat dilanjutkan, diperluas, dimodifikasi, atau disetop. Hal ini sangat penting karena biaya yang tidak sedikit untuk menunjang program-program pembangunan yang telah ditetapkan oleh Pemerintah harus benar-benar dapat memberikan manfaat yang besar bagi kepentingan masyarakat.

\section{REFERENSI}

Agustino, L. (2008). Dasar-Dasar Kebijakan Publik. Cetakan kedua. Bandung : Alfabeta.

Badjuri, H. A. dan Teguh, Y. (2003). Kebijakan Publik : Konsep dan Strategi. Cetakan Kedua. Semarang : Universitas Diponegoro.

Black, J., dan Dean, J.C. (1999). Champion. 1999. Metode dan Masalah Penelitian Sosial. Cetakan kedua. Terjemahan E. Koeswara, Dira Salam, Alfin Ruzhendi. Bandung : Refika Aditama.

Bungin, B. (2001). Metode Penelitian Sosial. Surabaya : Airlangga University Press.

Badan Perencanaan Pembangunan Daerah Kabupaten Kapuas Hulu. (2012). Data Pokok 2012 Kabupaten Kapuas Hulu. Putussibau. Badan Perencanaan Pembangunan Daerah Kabupaten Kapuas Hulu.

Badan Pusat Statistik Kabupaten Kapuas Hulu. 2012. Indikator Kesejahteraan Rakyat Kabupaten Kapuas Hulu Tahun 2012.

Balai Informasi Pertanian Kalimantan Selatan. (1995). Pembuatan Kerupuk Ikan Lundu. Banjar Baru.
Departemen Pertanian.

Creswell, J.W. (2009). Research Design : Qualitative, Quantitative, and Mixed Methods Approaches. Third Edition, California: Sage Publications Inc.

------.. (2010). Research Design : Pendekatan Kualitatif, Kuantitatif, dan Mixed. Edisi Ketiga. Cetakan I. Terjemahan Achmad Fawaid. Yogyakarta : Pustaka pelajar.

Danim, S. (1997). Pengantar Studi Penelitian Kebijakan. Jakarta : Bumi Aksara.

Dunn, W.N. (2000). Pengantar Analisis Kebijakan Publik. Edisi Kedua. Cetakan Keempat. Terjemahan : Samodra Wibawa, Diah Asitadani, Agus heruanto hadna, Erwan Agus Purwanto. Penyunting : Muhadjir Darwin. Yogyakarta : Gajah mada University Press.

Departemen Pertanian. (1989). Pembuatan Kerupuk Ikan dan Udang. Palangka Raya. Departemen Pertanian.

Eddy, A. dan Evi, L. (1989). Pengawetan dan Pengolahan Ikan. Yogyakarta. Kanisius.

Fauzi, A. (2005). Kebijakan Perikanan dan Kelautan. Jakarta : Gramedia Pustaka Utama.

Gulo,W. (2002), Metodolologi Penelitian, Jakarta :PT. Gramedia Widiasarana Indonesia

Islamy, M.,I.. (2009). Prinsip-prinsip Perumusan Kebijakan Negara. Jakarta : Bumi Aksara.

Irawan, P. (2007). Metodolgi Penelitian Administarsi. Jakarta : Universitas Terbuka.

Kementerian Kelautan dan Perikanan. 
(2012). Statistika Ekspor Hasil Indonesia. Jakarta. Kementerian Kelautan dan Perikanan.

Laporan Data Statistik Dinas Perikanan Kabupaten Kapuas Hulu Tahun 2012.

Laporan Akuntabilitas Kinerja Instansi Pemerintah (LAKIP) Dinas Perikanan Kabupaten Kapuas Hulu Tahun 2012.

Nugroho, D,R. (2003) . Kebijakan Publik Formulasi, Implementasi dan Evaluasi. Jakarta : PT.Elex Media Komputindo Kelompok Gramedia.

Peraturan Menteri Kelautan dan Perikanan Republik Indonesia (2016) No.37/PERMEN/KP/2016, Skala Usaha Pengolahan Ikan.

Rencana Strategis (RenStra) Dinas Perikanan Kabupaten Kapuas Hulu Tahun 2011-2015.

Robins, S.P. (2001). Prilaku Organisasi (Konsep Konversi, Aplikasi) Jakarta :PT. Prenhalindo.

Surat Keputusan Kepala Dinas Perikana Kabupaten Kapuas Hulu No. 7 tahun 2016, Penunjukan Pejabat Pengadaan Barang dan Jasa pada Bidang Pengolahan dan PemasaranHasil Perikanan Tahun Anggaran 2016.

Soenarko. (2000). Public Policy : Pengertian-pengertian Pokok Untuk Memahami dan Analisis Kebijakan Pemerintah. Surabaya : Airlangga University Press.

Sudarmayanti. (2001). Dasar-Dasar Pengetahuan Tentang Manajemen Perkantoran. Bandung: CV. Mandar Maju.

Suhardi, Suhardjo, Yuniarti, F. Kasijadi,
W. Istuti, A. Budijono, Jumadi dan Bonimin. 2006. Pengkajian Inovasi Teknologi Pengolahan. http//www. Litbang. Deptan. Go.id.

Tangkilisan,Hessel Nogi. (2003). Implementasi Kebijakan Publik Tranformasi Pikiran George Edward. Penerbit Lukman \& Yayasan Pembauran Administrasi Publik Indonesia Jakarta

Winarno. (2002). Kebijakan Publik Teori dan Proses. Jakarta : Media Pressind

Wahab. (2001). Analisis Kebijaksanaan. Jakarta: Bumi Aksara.

Winarno. (2007). Teori dan Proses Kebijaksanaan Publik. Yogyakarta: Med Press. 